\title{
NOWA USTAWA O SPÓŁDZIELNIACH ROLNIKÓW - WYBRANE ZAGADNIENIA
}

\section{Wstęp}

Dnia 4 października 2018 r. została uchwalona ustawa o spółdzielniach rolników ${ }^{1}$, która stworzyła podstawy prawne zakładania, organizacji i działalności spółdzielni rolników oraz ich związków². Nie ulega wątpliwości, że zrzeszanie się producentów rolnych jest niezmiernie istotne dla rozwoju rolnictwa i obszarów wiejskich. Współpraca jest potrzebna na różnych etapach prowadzenia działalności - począwszy od zakupu środków produkcji, poprzez korzystanie z maszyn rolniczych, sprzedaż plonów, doradztwo, aż po przetwórstwo ${ }^{3}$.

* Dr hab., prof. Uniwersytetu im. Adama Mickiewicza w Poznaniu; e-mail: suchon@ amu.edu.pl, https://orcid.org/0000-0002-5410-7853.

1 Dz. U. z 2018 r. poz. 2073 (dalej: ustawa o spółdzielniach rolników).

2 W uzasadnieniu do projektu ustawy o spółdzielniach rolników zostało zaakcentowane, że "[...] celem jest opracowanie przepisów, które w sposób kompleksowy będą regulowały zasady i sposób funkcjonowania spółdzielni stricte rolniczych, przez stworzenie zachęt do powoływania przez rolników tego typu podmiotów, a także lepszych warunków ekonomicznych do prowadzenia przez nich działalności. Zachęty, o których mowa, to w szczególności wyłączenie podmiotów, które uzyskały status spółdzielni rolników, z określonych obowiązków fiskalnych", rządowy projekt ustawy o spółdzielniach rolników z dnia 22 marca 2017 r., Druk nr 1425, http:/ / www.sejm.gov.pl/Sejm8.nsf/druk. xsp?nr=1425 [dostęp: 3.08.2019 r.]. Zob. też A. Suchoń, Uwagi na tle projektu ustawy o spótdzielniach rolników, Przegląd Prawa Rolnego 2017, nr 2, s. 191-208.

3 Zob. szerzej A. Suchon, Zrzeszanie się producentów rolnych, w: E. Klat-Górska, M. Korzycka, E. Kremer, P. Księżak, A. Suchoń, P. Wojciechowski, Instytucje prawa rolnego, Warszawa 2019, s. 423-442; A. Suchoń, Spótdzielczość w rolnictwie i na obszarach wiejskich, w: Prawo rolne, red. P. Czechowski, Warszawa 2019, s. 456-471 i cytowana tam literatura. 
W ostatnich latach powstało w Polsce ponad 1300 grup producentów rolnych (w tym więcej niż 500 w formie spółdzielni), które tak jak spółdzielnie rolników zrzeszają producentów rolnych. Mimo funkcjonowania nowych podmiotów, stan zorganizowania $w$ rolnictwie jest nadal niski ${ }^{4}$. Niektóre z założonych grup producentów rolnych zostały bowiem rozwiązane (obecnie działa nieco ponad 800 takich podmiotów) ${ }^{5}$. Nowy akt prawny z dnia 4 października 2018 r. przewiduje instrumenty prawne mające zachęcić osoby związane z rolnictwem do zakładania i przystępowania do spółdzielni rolników ${ }^{6}$. Powstaje jednak pytanie, czy będą one wystarczające, aby ożywić zainteresowanie ruchem spółdzielczym na obszarach wiejskich.

Głównym celem artykułu jest próba określenia prawnych uwarunkowań tworzenia i prowadzenia działalności przez spółdzielnie rolników oraz ustalenie, które z regulacji prawnych mogą zachęcać producentów rolnych do organizowania takich podmiotów albo też stanowić bariery w prowadzeniu tego rodzaju działalności. W tym kontekście warto się zastanowić, czy spółdzielnie rolników mają szanse rozwoju w obecnej sytuacji społeczno-gospodarczej. Dodatkowo podjęta zostanie próba wskazania specyficznych rozwiązań dotyczących spółdzielni rolników na tle dotychczasowej regulacji prawa spółdzielczego oraz cech charakterystycznych tych podmiotów. Problematyka jest szeroka, a objętość artykułu ograniczona, dlatego zaprezentowane zostaną tylko niektóre aspekty.

4 Według danych statystycznych w państwach Unii Europejskiej funkcjonuje około 22 tys. spółdzielni rolniczych, a całkowity ich obrót przekracza 347 mld euro. Mają więcej niż 50\% udziału w dostawach środków do produkcji rolniczej, a ponad $60 \%$ w skupie, przetwórstwie i marketingu produktów rolnych. Tak COGECA, Development of Agricultural Cooperatives in the EU, Brussels 2014, s. 6 i n. Zob. też COGECA, Agricultural Cooperatives in Europe. Main Issues and Trends, Brussels 2010, s. 5 i n.; Organizacja mazowieckiego rynku rolnego poprzez tworzenie grup producentów rolnych na bazie prawa spótdzielczego, red. W. Boguta, Z. Gumowski, K. Lachowski, Warszawa 2007, s. 27 i n.

5 Zob. rejestry grup producentów rolnych prowadzone przez Agencję Restrukturyzacji i Modernizacji Rolnictwa (ARiMR), https:/ / www.arimr.gov.pl/grupy-i-organizacje-producentow / rejestry-prowadzone-przez-arimr/rejestr-grup-producentow-rolnych. html [dostęp: 3.10.2019 r.]. Według stanu na październik 2019 r. wpisanych było około 850 grup producentów rolnych.

6 Szerzej na temat ustawy o spółdzielniach rolników np. J. Bieluk, Spółdzielnie rolników - konstrukcja prawna, Studia Iuridica Agraria 2018, t. 16, s. 13 i n.; A. Suchon, Legal aspects of the organisation and operation of agricultural co-operatives in Poland, Poznań 2019, s. 7 i n. 
Artykuł będzie koncentrował się na założycielach spółdzielni rolników, przedmiocie działalności, statucie, wkładach i udziałach, lustracji, współpracy pomiędzy spółdzielniami, instrumentach podatkowych. Wybór zagadnień nie jest przypadkowy. Rozwiązania prawne dotyczące wskazanych elementów przesądzają często o podjęciu decyzji przez producentów rolnych o założeniu i prowadzeniu spółdzielni. W ramach artykułu zostanie dokonana analiza wybranych regulacji prawnych ustawy o spółdzielniach rolników oraz ustawy z dnia 16 września 1982 r. - Prawo spółdzielcze ${ }^{7}$. Przywołanie tego drugiego aktu prawnego nie będzie jednak szerokie, ale związane z realizacją celu publikacji. Art. 3 ustawy o spółdzielniach rolników wskazuje bowiem, że w sprawach nieuregulowanych przepisami tego aktu stosuje się przepisy właśnie ustawy Prawo spółdzielcze. Ustawodawca nie uregulował całościowo wszystkich kwestii dotyczących działalności spółdzielni rolników w nowej ustawie. Wybrał podobną konstrukcję legislacyjną jak w przypadku spółdzielni socjalnych $^{8}$ czy spółdzielni mieszkaniowych ${ }^{9}$. Mianowicie w sprawach nieuregulowanych w ustawie z dnia 27 kwietnia 2006 r. o spółdzielniach socjalnych ${ }^{10}$ oraz ustawie z dnia 15 grudnia 2000 r. o spółdzielniach mieszkaniowych ${ }^{11}$ odwołał także do ustawy Prawo spółdzielcze.

\section{Zakładanie spółdzielni rolników}

Ustawa o spółdzielniach rolników określa, że spółdzielnia rolników jest dobrowolnym zrzeszeniem przede wszystkim rolników prowadzących gospodarstwo rolne $\mathrm{w}$ rozumieniu przepisów ustawy z dnia 15 listopada $1984 \mathrm{r}$. o podatku rolnym ${ }^{12}$ lub działalność rolniczą w zakresie działów specjalnych produkcji rolnej o zmiennym składzie osobowym i zmiennym funduszu udziałowym, które w interesie swoich członków

7 Tekst jednolity: Dz. U. z 2018 r. poz. 1285 z późn. zm.

8 Zob. szerzej M. Jedlińska, Spółdzielnie socjalne, w: System Prawa Prywatnego, t. 21. Prawo spótdzielcze, red. K. Pietrzykowski, Warszawa 2020, s. 794 i n.

9 Zob. szerzej J. Gajda, K. Królikowska, K. Pietrzykowski, J. Pisuliński, P. Zakrzewski, Spótdzielnie mieszkaniowe, w: System Prawa Prywatnego, t. 21. Prawo spótdzielcze, s. 449 i n.

10 Tekst jednolity: Dz. U. z 2018 r. poz. 1205 z późn. zm.

11 Tekst jednolity: Dz. U. z 2020 r. poz. 1465 z późn. zm.

12 Tekst jednolity: Dz. U. z 2019 r. poz. 1256 z późn. zm. 
prowadzi wspólną działalność gospodarczą. Spółdzielnia może także prowadzić działalność społeczną i oświatowo-kulturalną na rzecz swoich członków i ich środowiska. Co prawda członkami mogą być także nierolnicy (art. 4), ale podstawowymi spółdzielcami są rolnicy, o czym świadczy chociażby nazwa (firma). Omawiany podmiot musi bowiem zawierać oznaczenie „spółdzielnia rolników”.

Rozważania warto rozpocząć od udzielania odpowiedzi na pytanie, kto może utworzyć spółdzielnię rolników. Tak więc założycielami mogą być tylko rolnicy. Po dokonaniu analizy przywołanego art. 4 należy stwierdzić, że jest nim podmiot (osoba fizyczna, osoba prawna) po pierwsze, prowadzący gospodarstwo rolne w rozumieniu przepisów o podatku rolnym lub po drugie, działalność rolniczą w zakresie działów specjalnych produkcji rolnej ${ }^{13}$ będący producentem produktów rolnych lub grup tych produktów albo prowadzący chów lub hodowlę ryb. Konieczne jest zatem ustalenie pojęcia gospodarstwa rolnego, gdyż jego ujęcie w różnych aktach prawnych nie jest jednolite.

Za gospodarstwo rolne w świetle ustawy o podatku rolnym uważa się obszar użytków rolnych o łącznej powierzchni przekraczającej 1 ha lub 1 ha przeliczeniowy, stanowiących własność lub znajdujących się w posiadaniu osoby fizycznej, osoby prawnej albo jednostki organizacyjnej, w tym spółki nieposiadającej osobowości prawnej. Pojawia się pytanie, czy rolnikiem jest tylko podatnik podatku rolnego, czy każdy właściciel gruntów rolnych tworzących gospodarstwo. Zgodnie z art. 336 ustawy z dnia 23 kwietnia 1964 r. - Kodeks cywilny ${ }^{14}$ posiadaczem rzeczy jest ten, kto nią faktycznie włada, nie tylko jako właściciel (posiadacz samoistny), ale także jako użytkownik, zastawnik, najemca, dzierżawca lub mający inne prawo, z którym łączy się określone władztwo nad cudzą rzeczą (posiadacz zależny). Natomiast odrębnym zagadnieniem jest rozumienie terminu „podatnik podatku rolnego", którym jest przede wszystkim właściciel albo użytkownik wieczysty. Przy tym

13 Na marginesie warto dodać, że pojęcie i definicja rolnika występuje np. w art. 6 pkt 1 ustawy z dnia 20 grudnia 1990 r. o ubezpieczeniu społecznym rolników (tekst jednolity: Dz. U. z 2020 r. poz. 174 z późn. zm.) czy art. 4 rozporządzenia Parlamentu Europejskiego i Rady (UE) z dnia 17 grudnia 2013 r. ustanawiającego przepisy dotyczące płatności bezpośrednich dla rolników na podstawie systemów wsparcia w ramach wspólnej polityki rolnej oraz uchylające rozporządzenie Rady (WE) nr 637/2008 i rozporządzenie Rady (WE) nr 73/2009 (Dz. Urz. UE L 347 z 20.12.2013, s. 608).

14 Tekst jednolity: Dz. U. z 2019 r. poz. 1145, 1495, z 2020 r. poz. 1740 (dalej: K.c.). 
dzierżawcy (posiadacze zależni) są traktowani nierówno. Podatnikiem jest dzierżawca gruntów Skarbu Państwa i samorządu terytorialnego (art. 3 pkt 4 ustawy o podatku rolnym). Wyłączony z obowiązku uiszczania tej opłaty jest zaś dzierżawca gruntów prywatnych (wyjątek stanowi sytuacja, gdy grunty gospodarstwa rolnego zostały w całości lub w części wydzierżawione na podstawie umowy zawartej stosownie do przepisów o ubezpieczeniu społecznym rolników lub przepisów dotyczących uzyskiwania rent strukturalnych). Z umowy dzierżawy może co prawda wynikać, że do obowiązków dzierżawcy należy uiszczanie podatku rolnego, jednak będzie go płacił w imieniu wydzierżawiającego, na którego wystawiono nakaz zapłaty. Natomiast umowa dzierżawy, szczególnie ustna, nie musi przewidywać takiego postanowienia. Wtedy podatek płaci właściciel, wydzierżawiający.

Zasadne wydaje się przyjęcie, że spółdzielcą rolnikiem może być każdy podmiot prowadzący gospodarstwo rolne w rozumieniu przepisów o podatku rolnym, a nie tylko podatnik podatku rolnego ${ }^{15}$. Inna interpretacja byłaby właściwa, gdyby przepis stanowił, że członkiem spółdzielni rolników może być podmiot będący podatnikiem podatku rolnego ${ }^{16}$. Niemniej może się pojawić problem w zakresie udowodnienia, że osoba prowadzi gospodarstwo rolne $\mathrm{w}$ świetle ustawy o podatku rolnym. W przypadku podatników podatku rolnego sprawa jest prosta, gdyż dysponują decyzją podatkową. Natomiast dzierżawcy prywatnych gruntów rolnych takiego dokumentu nie posiadają (z wyjątkiem art. 3 ust. 3 ustawy o podatku rolnym). W takiej sytuacji uzasadnione wydaje się przyjęcie, że wystarczające będzie oświadczenie dzierżawcy (producenta rolnego) o prowadzeniu gospodarstwa rolnego w świetle ustawy o podatku rolnym. Należy podkreślić, że posiadacz zależny może nie dysponować pisemną umową dzierżawy, ważny jest bowiem także ustny kontrakt dzierżawy nieruchomości rolnych ${ }^{17}$.

15 Na temat podatników podatku rolnego zob. A. Suchoń, Z problematyki podatku rolnego, Przegląd Prawa Rolnego 2007, nr 2, s. 247-270 i cytowana tam literatura.

16 Do pojęcia podatnika podatku rolnego nawiązuje ustawa z dnia 14 grudnia $1995 \mathrm{r}$. o izbach rolniczych, tekst jednolity: Dz. U. z 2018 r. poz. 1027. Według art. 2 członkami samorządu rolniczego z mocy prawa są m.in. osoby fizyczne i prawne będące podatnikami podatku rolnego $\mathrm{w}$ rozumieniu przepisów o podatku rolnym.

17 Zob. szerzej A. Suchoń, Komentarz do przepisów o dzierżawie (art. 693-709 KC), w: Kodeks cywilny, t. 2. Komentarz. Art. 353-626, red. M. Gutowski, Warszawa 2018, s. 790-830. 
Rolnikiem jest także podmiot prowadzący działalność rolniczą w zakresie działów specjalnych. Ustawy podatkowe (np. ustawa z dnia 15 lutego 1992 r. o podatku dochodowym od osób prawnych ${ }^{18}$ ) określają, że działami specjalnymi produkcji rolnej są: uprawy w szklarniach i ogrzewanych tunelach foliowych, uprawy grzybów i ich grzybni, uprawy roślin in vitro, fermowa hodowla i chów drobiu rzeźnego i nośnego, wylęgarnie drobiu, hodowla i chów zwierząt futerkowych i laboratoryjnych, hodowla dżdżownic, hodowla entomofagów, hodowla jedwabników, prowadzenie pasiek oraz hodowla i chów innych zwierząt poza gospodarstwem rolnym $^{19}$. Nie stanowią działów specjalnych produkcji rolnej uprawy, hodowla i chów zwierząt w rozmiarach nieprzekraczających wielkości określonych w załączniku nr 2 do ustawy.

Podmioty powyższe (rolnicy) są producentami produktów rolnych lub grup tych produktów albo też prowadzą chów lub hodowlę ryb. Rozporządzenie Ministra Rolnictwa i Rozwoju Wsi z dnia 28 marca 2019 r. w sprawie wykazu produktów lub grup produktów, ze względu na które mogą być zakładane spółdzielnie rolników ${ }^{20}$, jak sama nazwa wskazuje, określa wykaz produktów lub grup produktów, ze względu na które mogą być zakładane spółdzielnie rolników. Zalicza się tu np. bydło domowe, trzodę chlewną, mleko, drób, owoce, warzywa, grzyby z rodzaju Agaricus, boczniaki, inne grzyby uprawne, rośliny przeznaczone do produkcji zielarskiej lub farmaceutycznej, miód naturalny, inne produkty pszczele oraz inne.

Wskazane wyżej osoby będące rolnikami mogą być założycielami spółdzielni rolników. Do powstania spółdzielni niezbędnych jest minimum 10 takich podmiotów. Spółdzielnia liczy więc co najmniej dziesięciu członków będących rolnikami, o ile statut nie wymaga innej liczby osób. Na uwagę zasługuje fakt, że członkami, ale nie założycielami spółdzielni mogą być także osoby niebędące producentami rolnymi. Podmioty takie mogą prowadzić działalność w zakresie przechowywania, magazynowania, sortowania, pakowania lub przetwarzania produktów rolnych, grup tych produktów, ryb wytworzonych przez rolników, a także działalność

18 Tekst jednolity: Dz. U. z 2019 r. poz. 865 z późn. zm.

19 Zob. szerzej J. Bieluk, Działy specjalne produkcji rolnej. Problemy prawne, Białystok 2013, s. 38 i n.; tenże, Pojęcie działalności rolniczej w ustawach o podatku dochodowym od osób fizycznych i od osób prawnych, Przegląd Prawa Rolnego 2008, nr 2 (4), s. 182-194. Zob. też A. Suchoń, Prawna koncepcja spótdzielni rolniczych, Poznań 2016, s. 164 i n.; taż, Jeszcze o pojęciu działalności rolniczej, Rejent 2017, nr 12.

20 Dz. U. z 2019 r. poz. 635. 
usługową wspomagającą rolnictwo, obejmującą świadczenie na rzecz rolników usług z wykorzystaniem maszyn, narzędzi lub urządzeń służących do wytwarzania przez tych rolników produktów rolnych lub grup tych produktów, ryb, zwanych dalej „podmiotami niebędącymi rolnikami”.

Dla założycieli każdego przedsiębiorstwa istotne są regulacje prawne dotyczące zakresu jego przyszłej aktywności. Przedmiot działalności spółdzielni rolników w ustawie o spółdzielniach rolników określony został szeroko i obejmuje: 1) planowanie prowadzonej przez rolników produkcji produktów lub grup produktów i dostosowywanie jej do warunków rynkowych, ze szczególnym uwzględnieniem jej ilości i jakości; 2) koncentrację podaży oraz organizowanie zbycia produktów lub grup produktów wyprodukowanych przez rolników; 3) koncentrację popytu oraz organizowanie nabycia niezbędnych rolnikom środków do produkcji produktów lub grup produktów (art. 6 ust. 1) ${ }^{21}$.

Spółdzielnia rolników, oprócz powyższej aktywności, może prowadzić inną działalność gospodarczą (fakultatywną) w obszernym i zróżnicowanym zakresie, m.in. przechowywania, konfekcjonowania i standaryzacji produktów lub grup produktów, przetwarzania produktów lub grup produktów wyprodukowanych przez rolników oraz obrotu uzyskanymi $\mathrm{w}$ ten sposób produktami przetworzonymi; świadczenia na rzecz rolników usług związanych z wytwarzaniem przez nich produktów lub grup produktów; zbywania produktów lub grup produktów wyprodukowanych przez rolników; upowszechniania wśród swoich członków korzystnych dla środowiska metod uprawy, technologii produkcji lub metod gospodarki odpadami; prowadzenia działalności usługowej na rzecz swoich członków innej niż świadczenie usług, o których mowa w pkt 3 (przychody z prowadzenia tej działalności nie mogą łącznie przekroczyć $25 \%$ przychodów spółdzielni rolników uzyskanych w danym roku obrotowym). Należy pozytywnie ocenić szerokie ujęcie przedmiotu działalności spółdzielni rolników. Na uwagę zasługuje przede wszystkim możliwość przetwarzania produktów rolnych dostarczonych przez członków. Jest to niezmierne ważne $\mathrm{w}$ aspekcie udziału producentów rolnych $\mathrm{w}$ kolejnym etapie łańcucha żywnościowego.

${ }^{21}$ J. Bieluk, Spótdzielnie rolników..., s. 13 i n. 


\section{Statut i organy spółdzielni rolników}

Nie ulega wątpliwości, że dla podjęcia decyzji przez rolników o założeniu spółdzielni istotne są informacje o procedurze jej utworzenia. Trzeba zatem przyjrzeć się formie i treści statutu. Czy wystarczy zwykła forma pisemna, czy, tak jak we Włoszech, musi to być akt notarialny?22 Według art. 6 ustawy Prawo spółdzielcze osoby zamierzające założyć spółdzielnię uchwalają statut, potwierdzając jego przyjęcie przez złożenie pod nim swoich podpisów. Poza postanowieniami określonymi $\mathrm{w}$ art. 5 § 1 wspomnianego aktu prawnego statut spółdzielni rolników zawiera m.in. warunki przyjmowania do spółdzielni członków będących rolnikami i podmiotów nimi niebędących (art. 5 ustawy o spółdzielniach rolników). Określenie tych wymogów jest szczególnie istotne, gdyż według art. 7 ust. 3 ustawy o spółdzielniach rolników spółdzielnia nie może odmówić przyjęcia rolnika albo podmiotu niebędącego rolnikiem, jeżeli spełnia on wymagania określone w ustawie oraz statucie. W statucie spółdzielni rolników określa się także minimalny okres członkostwa, który nie może być krótszy niż rok obrotowy. W dokumencie tym zawarte są również zasady i zakres dostarczania przez członków informacji dotyczących w szczególności powierzchni uprawy, plonów oraz wielkości produkcji produktów lub grup produktów; obowiązujące zasady produkcji, w tym te dotyczące jakości i ilości, oraz sposoby przygotowywania produktów lub ich grup do sprzedaży czy sankcje wobec członka spółdzielni rolników, który nie wypełnia nałożonych na niego obowiązków statutowych lub nie spełnia wymogów określonych w ustawie, w tym przyczyny wykluczenia i wykreślenia członka spółdzielni rolników z tej spółdzielni.

Odnotować należy problemy związane z określeniem charakteru prawnego statutu. Jak podkreślił K. Pietrzykowski, zagadnienie to należy do najbardziej spornych kwestii teoretycznych prawa spółdzielcze$\mathrm{go}^{23}$. W judykaturze przeważa stanowisko, że statut to szczególny rodzaj umowy (pkt 1). Popiera je także autorka niniejszego artykułu. Jak wynika z wielu wyroków Sądu Najwyższego, postanowienia statutu stanowią

22 Zob. A. Suchoń, Spółdzielnie w rolnictwie i na terenach wiejskich we Włoszech, Kwartalnik Prawa Prywatnego 2013, t. 22, nr 4, s. 891-919.

23 Tak K. Pietrzykowski, Pojęcie spółdzielni, w: System Prawa Prywatnego, t. 4. Prawo rzeczowe, red. E. Gniewek, Warszawa 2007, s. 318 i n. 
umownie wprowadzone normy obowiązujące spółdzielców i spółdzielnię, czego konsekwencją jest to, że instytucjonalnie jest on związany z reżimem cywilnych czynności prawnych ${ }^{24}$. Stąd jego postanowienia powinny być tłumaczone według dyrektyw wynikających z art. 65 K.c. ${ }^{25}$ Co więcej, postanowienia statutu spółdzielni $\mathrm{w}$ kwestiach uregulowanych $\mathrm{w}$ nim na podstawie zawartego $\mathrm{w}$ przepisach spółdzielczych odesłania mogą być uznane za prawo materialne $\mathrm{w}$ rozumieniu art. $393^{1}$ pkt 1 Kodeksu postępowania cywilnego ${ }^{26}$. Zgodnie $\mathrm{z}$ zasadą swobody umów postanowienia statutu mogą być kształtowane dowolnie, z uwzględnieniem jednak granic swobody określonych $w$ art. $353^{1}$ K.c. ${ }^{27}$ Oznacza to, że strony zawierające umowę mogą ułożyć stosunek prawny według swego uznania, o ile jego treść lub cel nie są sprzeczne z właściwością (naturą) stosunku, ustawą ani zasadami współżycia społecznego. W przypadku spółdzielni rolników będą to regulacje ustawy Prawo spółdzielcze oraz ustawy o spółdzielniach rolników.

Nie tylko jednak podpisanie statutu, a potem rejestracja w Krajowym Rejestrze Sądowym są istotne przy zakładaniu spółdzielni. W świetle przepisów założyciele dokonują wyboru zarządu i rady nadzorczej. Nie ulega wątpliwości, że sprawne i efektywne działanie tego pierwszego obligatoryjnego organu z reguły przyczynia się do rozwoju spółdzielni. Statut może przewidywać zarząd jedno- lub wieloosobowy i ustalać wymagania, jakie powinna spełniać osoba wchodząca w skład tego organu. Mogą to być osoby z grona spółdzielców albo spoza. W przypadku zarządu ustawa o spółdzielniach rolników wprowadza dodatkowe regulacje dotyczące odpowiedzialności za niepodjęcie działań w niekorzystnej sytuacji finansowej czy obowiązków związanych z lustracją. Według art. 18 ustawy o spółdzielniach rolników kto, będąc członkiem zarządu spółdzielni rolników albo likwidatorem, nie zgłasza wniosku o upadłość spółdzielni rolników, mimo powstania warunków uzasadniających upadłość spółdzielni, podlega grzywnie, karze ograniczenia wolności albo pozbawienia wolności do roku.

24 Np. uchwała SN z dnia 23 maja 1989 r., III CZP 34/89, OSNC 1990, nr 6, poz. 80; wyrok SN z dnia 15 kwietnia 1999 r., I CKN 1088/97, OSNC 1999, nr 11, poz. 193 czy wyrok SN z dnia 25 lipca 2003 r., V CK 117/02, LEX nr 172830.

25 Por. uchwałę SN z dnia 23 maja 1989 r., III CZP 34/89, OSNC 1990, nr 6, poz. 80 i wyrok SN z dnia 15 kwietnia 1999 r., I CKN 1088/97, OSNC 1999, nr 11, poz. 193.

26 Por. wyrok SN z dnia 30 września 2009 r., V CSK 86/09, LEX nr 627242.

27 Tamże. 
Kolejnym obligatoryjnym organem spółdzielni jest rada nadzorcza. Prawo spółdzielcze wskazuje, że składa się ona z co najmniej trzech członków. Ustawa o spółdzielniach rolników określa, że w skład rady wchodzą tylko członkowie będący rolnikami. Przepisy ustawy o spółdzielniach rolników poświęcają niewiele uwagi działalności zarządu i rady nadzorczej. Zastosowanie mają zatem regulacje prawne ustawy Prawo spółdzielcze.

\section{Wpisowe, udziały, wkłady, fundusze w spółdzielni rolników}

Członek spółdzielni jest zobowiązany do wniesienia wpisowego z tytułu przystąpienia do spółdzielni2 ${ }^{28}$. Termin dokonania tej czynności powinien określać statut, a w przypadku jego naruszenia zastosowanie ma art. 471 K.c. Przepisy ustawy Prawo spółdzielcze nie wprowadzają żadnych wytycznych odnośnie do ustalenia wysokości wpisowego. Nie powinno ono jednak być zbyt wysokie, gdyż ograniczałoby dostęp do spółdzielni dla nowych członków, czyli naruszało zasadę otwartych drzwi. Przykładowo ustawa z dnia 29 października 1920 r. o spółdzielniach ${ }^{29}$ wskazywała, że wpisowe nie może przewyższać wysokości połowy udziału ${ }^{30}$.

Artykuł 10 ustawy o spółdzielniach rolników stanowi, że statut może wskazywać, iż wysokość wpisowego wynosi: 1) określoną kwotę albo 2) iloraz określonej $w$ statucie części ułamkowej funduszu zasobowego spółdzielni rolników i liczby członków spółdzielni rolników - według stanu na koniec roku kalendarzowego bezpośrednio poprzedzającego rok przystąpienia członka do spółdzielni rolników.

Spółdzielca jest także zobowiązany do wniesienia zadeklarowanych udziałów stosownie do postanowień statutu. Można je podzielić na obowiązkowe, czyli niezbędne, aby zostać włączonym w poczet członków spółdzielni, oraz nieobowiązkowe (zwane także udziałami dalszymi) ${ }^{31}$. Ustawa o spółdzielniach rolników wprowadza nowe rozwiązania

28 Tak P. Zakrzewski, Majątek spółdzielni, Warszawa 2003, s. 69.

29 Dz. U. z 1920 r. Nr 111, poz. 733.

30 Tak P. Zakrzewski, Majątek..., s. 69.

31 Wyrok SA w Szczecinie z dnia 24 sierpnia 2011 r., I ACa 433/11, OSASz 2012, nr 1, s. 43-68. 
prawne dotyczące niektórych aspektów związanych z udziałami, które ocenić należy pozytywnie $\mathrm{w}$ aspekcie prowadzonej działalności związanej z rolnictwem. Statut może mianowicie przewidywać coroczne ustalanie liczby udziałów, do których mają prawo poszczególni spółdzielcy, proporcjonalnie do posiadanego przez nich udziału procentowego w łącznej wartości zakupionych od członków przez spółdzielnię produktów lub grup produktów w roku obrotowym bezpośrednio poprzedzającym rok, w którym ustalana jest liczba udziałów. W takim przypadku: 1) liczba udziałów, do jakich mają prawo poszczególni członkowie, jest ustalana na podstawie uchwały walnego zgromadzenia, podejmowanej większością co najmniej 2/3 głosów w obecności co najmniej połowy uprawnionych do głosowania; 2) statut określa sposób i terminy realizacji dopłat dokonywanych na udziały albo zwrotu wpłat dokonanych na udziały.

Ustawa o spółdzielniach rolników porusza także problematykę zbycia udziałów, wprowadzając nowe rozwiązania w porównaniu z ustawą Prawo spółdzielcze. Można stwierdzić, że uwzględniają one specyfikę działalności rolniczej. Po pierwsze, były członek spółdzielni rolników oraz osoba - którą zmarły członek wskazał jako osobę, której spółdzielnia rolników jest obowiązana zwrócić udziały po jego śmierci - może zbyć swoje udziały innemu członkowi tej spółdzielni. Po drugie, podejmuje kwestię udziałów w przypadkach wypowiedzenia lub zaprzestania prowadzenia działalności rolniczej przez członka spółdzielni. W art. 11 ust. 6 ustawy o spółdzielniach rolników wskazano, że członek spółdzielni rolników, który wystąpił ze spółdzielni za wypowiedzeniem lub został wykreślony z powodu zaprzestania prowadzenia gospodarstwa rolnego lub działu specjalnego produkcji rolnej, może w terminie 6 miesięcy od dnia ustania członkostwa przenieść swoje udziały na osobę spełniającą wymagania wskazane $w$ ustawie. Warunkiem jest przejęcie przez nią i prowadzenie gospodarstwa rolnego spółdzielcy lub działu specjalnego produkcji rolnej. Dodatkowy wymóg to uzyskanie członkostwa spółdzielni albo złożenie deklaracji przystąpienia do tego podmiotu (art. 11 ust. 6 ustawy o spółdzielniach rolników). Ustawodawca postanowił także, że przekazanie gospodarstwa rolnego musi nastąpić nieodpłatnie (na podstawie np. umowy darowizny czy umowy z następcą). Powyższej możliwości dotyczącej udziałów nie stosuje się, gdy przeniesienie własności gospodarstwa rolnego lub działu specjalnego produkcji rolnej nastąpiło odpłatnie. Ustawa o spółdzielniach rolników wskazuje, że umowę przenoszącą 
własność udziałów w przypadkach wskazanych powyżej zawiera się pod rygorem nieważności $\mathrm{w}$ formie pisemnej $\mathrm{z}$ podpisami notarialnie poświadczonymi.

Pozostaje pytanie, co w przypadku, gdy nowy właściciel gospodarstwa nie został członkiem spółdzielni rolników albo nie złożył deklaracji przystąpienia do tej spółdzielni, czy gdy przeniesienie przez członka spółdzielni własności gospodarstwa rolnego lub działu specjalnego produkcji rolnej nastąpiło $\mathrm{w}$ wyniku odpłatnego nabycia. $\mathrm{W}$ takiej sytuacji udział byłego członka wypłaca się na podstawie zatwierdzonego sprawozdania finansowego za rok, w którym członek przestał należeć do spółdzielni rolników (sposób i terminy wypłaty określa statut).

W aspekcie zorganizowania przedsiębiorstwa spółdzielczego i potem jego funkcjonowania istotny jest przepis ustawy Prawo spółdzielcze, stanowiący, że statut może przewidywać wnoszenie przez członków wkładów na własność spółdzielni lub do korzystania z nich przez spółdzielnię na podstawie innego stosunku prawnego (art. $20 \S 2$ ustawy Prawo spółdzielcze). W odniesieniu do takiej sytuacji dokument ten powinien określać charakter i zakres przysługującego spółdzielni prawa do wkładów, wysokość oraz ich rodzaj. Jeżeli są to wkłady niepieniężne, winien podawać terminy ich wnoszenia, zasady wyceny i zwrotu w przypadku likwidacji spółdzielni, wystąpienia członka lub ustania członkostwa z innych przyczyn, a także w innych przypadkach przewidzianych w statucie. Rola wkładu polega na dostarczaniu spółdzielni odpowiedniej bazy majątkowej, potrzebnej do prowadzenia działalności gospodarczej, np. nieruchomości z magazynami na zboża czy budynkami wykorzystywanym do działalności przetwórczej². Ustawa o spółdzielniach rolników wskazuje w art. 12, że członek będący właścicielem wniesionego do spółdzielni wkładu niepieniężnego może nim rozporządzać. Jest jednak zobowiązany powiadomić na piśmie spółdzielnię rolników o zamiarze zbycia takiego wkładu co najmniej na 12 miesięcy przed datą dokonania tej czynności, o ile w statucie nie został wskazany wcześniejszy termin.

Ustawa o spółdzielniach rolników zawiera także przepisy dotyczące funduszów. W tego rodzaju spółdzielniach tworzy się zasadnicze fundusze własne: 1) udziałowy - pozyskany z udziałów członkowskich; 2) zasobowy - złożony z opłat wpisowych dokonanych przez członków oraz nie mniej niż 10\% nadwyżki bilansowej; 3) wzajemnościowy - na który

32 Tak P. Zakrzewski, Majątek..., s. 79. 
składają się wpłaty w wysokości nie mniejszej niż 3\% nadwyżki bilansowej, przeznaczony na rozwój i promocję spółdzielni rolników. Spółdzielnia może tworzyć inne fundusze własne przewidziane w odrębnych przepisach lub w jej statucie.

Prawo do funduszu udziałowego przechodzi na nowego członka, o ile strony nie ustalą inaczej (chodzi o osobę, która wystąpiła ze spółdzielni lub została wykreślona z powodu zaprzestania prowadzenia gospodarstwa rolnego lub działu specjalnego produkcji rolnej i dokonała przeniesienia swoich udziałów na osobę, która przejęła i prowadzi jego gospodarstwo rolne lub dział specjalny produkcji rolnej). Prawo do funduszu udziałowego przysługuje spadkobiercom zmarłego członka. Natomiast środki pieniężne zgromadzone na rachunku funduszu wzajemnościowego przeznacza się na rozwój i promocję spółdzielni rolników. Część nadwyżki bilansowej pozostałej po dokonaniu odpisów na fundusz przeznacza się na cele wskazane w uchwale walnego zgromadzenia.

\section{Współpraca pomiędzy spółdzielniami rolników}

Dla funkcjonowania spółdzielni, w tym rolników, istotne są regulacje prawne dotyczące współpracy pomiędzy tymi podmiotami. Inicjatywy tego rodzaju pozwalają np. na zwiększenie ich znaczenia i konkurencyjności na rynkach rolnych, poszerzenie doświadczenia oraz zakresu działalności. Kooperacja pomiędzy spółdzielniami rolników wpisuje się zarówno w piątą zasadę spółdzielczą (kształcenia, szkolenia i informacji), jak i szóstą (współpracy pomiędzy spółdzielniami) ${ }^{33}$. Ustawa o spółdzielniach rolników określa, że spółdzielnie rolników mają prawo zakładać związki spółdzielni rolników prowadzące w imieniu i na rzecz swoich członków działalność w zakresie, o którym mowa w art. 6 ust. 2 tego aktu (lub przystępować do takich związków), np. przechowywania, konfekcjonowania i standaryzacji produktów lub grup produktów wyprodukowanych przez rolników; przetwarzania produktów lub grup produktów wyprodukowanych przez rolników oraz obrotu uzyskanymi w ten sposób produktami przetworzonymi; świadczenia na rzecz rolników usług

33 Tenże, Zasady Międzynarodowego Związku Spółdzielczego, Kwartalnik Prawa Prywatnego 2005, t. 14, nr 1 . 
związanych z wytwarzaniem przez nich produktów lub grup produktów; zbycia produktów lub grup produktów wyprodukowanych przez rolników; upowszechniania wśród swoich członków korzystnych dla środowiska metod uprawy, technologii produkcji lub metod gospodarki odpadami. Według ustawy związek spółdzielni rolników może prowadzić również działalność społeczną i oświatowo-kulturalną na rzecz członków spółdzielni rolników będącej członkiem tego związku. Do związków spółdzielni rolników stosuje się przepisy ustawy Prawo spółdzielcze zawarte w części I w tytule I dotyczące spółdzielni, których członkami zgodnie ze statutem są wyłącznie osoby prawne (art. 9 ustawy o spółdzielniach rolników). Krajowa Rada Spółdzielcza prowadzi rejestr związków spółdzielni rolników. Podmiot ten określa zasady prowadzenia rejestru i dane w nim uwidocznione.

Warto także wspomnieć o związkach rewizyjnych. Mianowicie ustawa Prawo spółdzielcze stanowi, że spółdzielnie mogą zakładać związki rewizyjne i przystępować do nich. Liczba założycieli związku rewizyjnego nie może być mniejsza niż dziesięć. Ich celem jest zapewnienie pomocy zrzeszonym w nim spółdzielniom w ich działalności statutowej. Do zadań związku rewizyjnego należy m.in.: przeprowadzanie lustracji zrzeszonych spółdzielni; prowadzenie na rzecz zrzeszonych spółdzielni działalności: instruktażowej, doradczej, kulturalno-oświatowej, szkoleniowej i wydawniczej; reprezentowanie interesów zrzeszonych spółdzielni wobec organów administracji państwowej i organów samorządu terytorialnego. Rejestr związków rewizyjnych prowadzi Krajowa Rada Spółdzielcza (art. 241 ustawy Prawo spółdzielcze) ${ }^{34}$.

\section{Spółdzielnie rolników a spółdzielcze grupy producentów rolnych}

Kwestią wartą poruszenia jest to, czy działające spółdzielnie, w tym spółdzielcze grupy producentów rolnych, spółdzielcze organizacje producentów rolnych (także owoców i warzyw), spełniające wymagania wskazane w ustawie o spółdzielniach rolników będą mogły zostać uznane za spółdzielnie rolników. Na marginesie warto wyjaśnić, że grupy producentów rolnych prowadzą działalność podobną do spółdzielni rolników.

\footnotetext{
34 https://krs.org.pl/regionalne-spodzielcze-zwizki-rewizyjne [dostęp: 1.08.2019 r.].
} 
Według art. 2 ustawy z dnia 15 września 2000 r. o grupach producentów rolnych i ich związkach oraz o zmianie innych ustaw ${ }^{35}$ osoby fizyczne, jednostki organizacyjne nieposiadające osobowości prawnej oraz osoby prawne, które $\mathrm{w}$ ramach działalności rolniczej prowadzą: 1) gospodarstwo rolne $\mathrm{w}$ rozumieniu przepisów o podatku rolnym lub 2) dział specjalny produkcji rolnej mogą organizować się w grupy producentów rolnych $\mathrm{w}$ celu dostosowania produktów rolnych i procesu produkcyjnego do wymogów rynkowych, wspólnego wprowadzania towarów do obrotu, w tym przygotowania i centralizacji sprzedaży oraz dostawy towarów do odbiorców hurtowych, ustanowienia wspólnych zasad dotyczących informacji o produkcji ze szczególnym uwzględnieniem zbiorów i dostępności produktów rolnych, rozwijania umiejętności biznesowych, marketingowych oraz organizowania i ułatwiania procesów wprowadzania innowacji, a także ochrony środowiska naturalnego.

$\mathrm{Z}$ jednej strony odnotować należy interpretacje, według których ustawa o spółdzielniach rolników dotyczy wyłącznie nowo utworzonych podmiotów, z drugiej zaś głoszące, że już funkcjonujące spółdzielnie producentów rolnych, jeżeli będą spełniały wskazane tam wymagania, po uzupełnieniu statutu i nazwy (w Krajowym Rejestrze Sądowym) o zwrot „spółdzielnie rolników” będą mogły działać jako takie podmioty ${ }^{36}$.

W opinii autorki ta druga wykładnia jest bardziej zasadna. Przede wszystkim żaden z przepisów nie wskazuje, że aktualnie działające i spełniające wymogi spółdzielnie nie mogą zmienić statutu zgodnie z nową ustawą o spółdzielniach rolników i dodać przy tym w nazwie określenie „spółdzielnie rolników” oraz złożyć wniosku o wpis zmian do Krajowego Rejestru Sądowego. Uważam, że dla zrzeszania producentów rolnych, tworzenia stabilnej struktury zasadne byłoby przyjęcie interpretacji, że spółdzielnia spełniająca wymagania z ustawy o spółdzielniach rolników może zostać uznana za spółdzielnię rolników. Proces likwidacji spółdzielczej grup producentów rolnych łączy się z kosztami i trwa. Trudno będzie

35 Tekst jednolity: Dz. U. z 2018 r. poz. 1026 (dalej: ustawa o grupach producentów rolnych).

36 Referaty i dyskusja w czasie konferencji naukowej w dniu 29.03.2019 r., pt. „Praktyczne aspekty tworzenia spółdzielni rolników z uwzględnieniem dorobku uznanych grup i organizacji producentów", w Centrum Doradztwa Rolniczego Marszew: Ł. Goździk (MRiRW, Warszawa), referat pt. Zasady organizowania i funkcjonowania Spótdzielni rolników oraz jej wptyw na poprawe pozycji rynkowej producentów rolnych; A. Suchoń (UAM), referat pt. Prawne możliwości i bariery w zakresie wzmocnienia pozycji rynkowej producentów rolnych zrzeszonych w grupach, organizacjach producentów rolnych, spółdzielniach rolników. 
utworzyć spółdzielnię rolników po zakończeniu działalności grupy producentów rolnych.

Powstaje także pytanie, czy nowo powstałe spółdzielnie rolników będą mogły ubiegać się o wpis do rejestru grup producentów rolnych. W tym celu należy się odwołać do ustawy o grupach producentów rolnych, według której w pierwszej kolejności należy utworzyć osobę prawną. Dopiero potem podmiot zarejestrowany w Krajowym Rejestrze Sądowym jako spełniający wymagania przedsiębiorcy może starać się o uznanie jako grupa producentów rolnych przez Agencję Restrukturyzacji i Modernizacji Rolnictwa (decyzja i wpis do rejestru). Skoro spółdzielnia rolników jest osobą prawną, to w świetle przepisów nie ma przeciwwskazań, aby starała się o status grupy producentów rolnych, o ile oczywiście spełnione będę zasady wynikające z ustawy o grupach producentów rolnych. $Z$ tego aktu prawnego wynika m.in., że grupa producentów rolnych prowadzi działalność jako przedsiębiorca mający osobowość prawną, pod warunkiem że: została utworzona przez producentów jednego produktu rolnego; każdy z członków grupy w każdym roku działalności grupy produkuje oraz sprzedaje do grupy co najmniej $80 \%$ wyprodukowanych przez siebie produktów lub grup produktów, ze względu na które grupa została utworzona.

\section{Lustracja spółdzielni rolników}

Dokonując oceny regulacji prawnych dotyczących funkcjonowania spółdzielni rolników wspomnieć należy o lustracji ${ }^{37}$. Wpływa ona pozytywnie na kondycję spółdzielni i przyczynia się do rozwoju tego podmiotu. Ustawa Prawo spółdzielcze określa cele lustracji szeroko, zaliczając do nich: sprawdzenie przestrzegania przez spółdzielnię przepisów prawa i postanowień statutu; prowadzenie działalności w interesie ogółu członków; kontrolę gospodarności, celowości i rzetelności realizacji przez spółdzielnię jej celów ekonomicznych, socjalnych oraz kulturalnych; wskazywanie członkom na nieprawidłowości w działalności organów spółdzielni; udzielanie organizacyjnej i instruktażowej pomocy

37 Słowo „lustracja” wywodzi się od łacińskiego lustrare - oczyszczać, zob. R. Bierzanek, Prawo spółdzielcze w zarysie, Warszawa 1984, s. 216 i n. 
w usuwaniu stwierdzonych nieprawidłowości oraz w usprawnieniu działalności spółdzielni ${ }^{38}$.

Przepisy wprowadzają zasadę, że każda spółdzielnia jest zobowiązana przynajmniej raz na 3 lata, a w okresie pozostawania w stanie likwidacji corocznie poddawać się lustracyjnemu badaniu legalności. Obejmuje ono okres od poprzedniej lustracji. Art. 15 ustawy o spółdzielniach rolników wskazuje, że lustracja jest przeprowadzana również w zakresie spełniania przez spółdzielnię rolników warunków, o których mowa w art. 4-9 (czyli np. w zakresie wymagań dotyczących członków, przedmiotu działalności, statutu i in.). Pozostaje jeszcze pytanie o podmioty ją wykonujące. Otóż lustracją zajmują się przede wszystkim właściwe związki rewizyjne w spółdzielniach w nich zrzeszonych. Natomiast spółdzielnie niezrzeszone $\mathrm{w}$ związkach rewizyjnych zlecają odpłatne przeprowadzenie lustracji wybranemu związkowi rewizyjnemu ${ }^{39}$ lub Krajowej Radzie Spółdzielczej.

Zgodnie z omawianą ustawą kto, będąc członkiem organu spółdzielni rolników albo likwidatorem wbrew przepisom ustawy 1) nie poddaje spółdzielni rolników lustracji, 2) nie udziela lub udziela niezgodnych ze stanem faktycznym wyjaśnień lustratorowi, nie dopuszcza go do pełnienia obowiązków lub nie przedkłada stosownych dokumentów, 3) nie udostępnia członkom spółdzielni rolników protokołu lustracji, 4) nie zwołuje walnego zgromadzenia, zebrania przedstawicieli albo zebrań grup członkowskich poprzedzających zebranie przedstawicieli, 5) nie przygotowuje w terminie dokumentów dotyczących dokonania podziału w spółdzielni, podlega grzywnie albo karze ograniczenia wolności. Co więcej, kto, będąc członkiem organu spółdzielni rolników albo likwidatorem, ogłasza dane nieprawdziwe albo przedstawia je organom spółdzielni rolników, władzom państwowym, członkom spółdzielni rolników lub lustratorowi, podlega grzywnie, karze ograniczenia albo pozbawienia wolności.

38 Zob. szerzej K. Pietrzykowski, Spótdzielnie mieszkaniowe. Komentarz, 2013 [baza danych Legalis], komentarz do art. 91 ustawy Prawo spółdzielcze - Nb 4.

39 https://krs.org.pl/krajowe-spodzielcze-zwizki-rewizyjne [dostęp: 3.08.2019 r.]. 


\section{Instrumenty finansowe}

Przepisy przewidują instrumenty finansowe mające zachęcić do zakładania spółdzielni rolników. Warto wspomnieć przede wszystkim o dwóch. Według ustawy z dnia 15 lutego 1992 r. o podatku dochodowym od osób prawnych art. $17 \mathrm{w}$ ust. 1 pkt 49a zwalnia się od podatku dochodowego od osób prawnych dochody spółdzielni rolników w rozumieniu ustawy o spółdzielniach rolników prowadzącej działalność jako mikroprzedsiębiorstwo w rozumieniu załącznika I do rozporządzenia Komisji (UE) nr 651/2014 z dnia 17 czerwca 2014 r., uznającego niektóre rodzaje pomocy za zgodne z rynkiem wewnętrznym w zastosowaniu art. 107 i 108 Traktatu pochodzące ze zbycia produktów rolnych lub grup tych produktów, lub ryb, ze względu na które spółdzielnia rolników została założona, wyprodukowanych $\mathrm{w}$ gospodarstwach lub działach specjalnych produkcji rolnej jej członków ${ }^{40}$.

Powyższy instrument finansowy należy ocenić pozytywnie, jednak jego zastosowanie jest ograniczone $\mathrm{w}$ aspekcie prowadzonej działalności przez spółdzielnie. Po pierwsze, zwolnienie to odnosi się tylko do zbycia produktów rolnych lub ryb, ze względu na które spółdzielnia rolników została założona, wyprodukowanych w gospodarstwach lub działach specjalnych produkcji rolnej jej członków. Ustawodawca nie wspomina o innych rodzajach działalności spółdzielni rolników. Jak zostało wskazane, zakres działalności spółdzielni rolników może być szeroki i dotyczyć przetwórstwa czy świadczenia usług rolniczych.

Na marginesie warto wspomnieć, że zgodnie z art. 2 ustawy o podatku dochodowym od osób prawnych przepisów ustawy nie stosuje się do: przychodów z działalności rolniczej, z wyjątkiem dochodów z działów specjalnych produkcji rolnej. Działalnością rolniczą jest aktywność polegająca na wytwarzaniu produktów roślinnych lub zwierzęcych w stanie nieprzetworzonym (naturalnym) z własnych upraw albo hodowli lub chowu, w tym również produkcja materiału siewnego, szkółkarskiego, hodowlanego oraz reprodukcyjnego, produkcja warzywnicza gruntowa,

40 W kategorii MŚP (Sektor małych i średnich przedsiębiorstw) mikroprzedsiębiorstwo definiuje się jako zatrudniające mniej niż 10 pracowników, którego roczny obrót lub roczna suma bilansowa nie przekraczają 2 milionów euro. Zob. rozporządzenie Komisji (UE) nr 651/2014 z dnia 17 czerwca 2014 r., Dz. Urz. UE L 187/1 z 26.06.2014. 
szklarniowa i pod folią, produkcja roślin ozdobnych, grzybów uprawnych i sadownicza, hodowla i produkcja materiału zarodowego zwierząt.

Po drugie, z omawianego instrumentu finansowego mogą skorzystać tylko spółdzielnie rolników będące mikroprzedsiębiorcami. W świetle załącznika I do rozporządzenia Komisji (UE) nr 651/2014, a także ustawy z dnia 6 marca 2018 r. - Prawo przedsiębiorców ${ }^{41}$ jest to przedsiębiorca, który w co najmniej jednym roku z dwóch ostatnich lat obrotowych spełniał łącznie następujące warunki: a) zatrudniał średniorocznie mniej niż 10 pracowników oraz b) osiągnął roczny obrót netto ze sprzedaży towarów, wyrobów i usług oraz z operacji finansowych nieprzekraczający równowartości w złotych 2 milionów euro lub sumy aktywów jego bilansu sporządzonego na koniec jednego z tych lat nie przekroczyły równowartości w złotych 2 milionów euro.

Niektóre spółdzielnie rolników będą mogły skorzystać także z innych preferencji podatkowych. Według znowelizowanej ustawy z dnia 12 stycznia $1991 \mathrm{r}$. o podatkach i opłatach lokalnych ${ }^{42}$ zwalnia się od podatku od nieruchomości budynki i budowle lub ich części oraz zajęte pod nie grunty wykorzystywane przez spółdzielnię rolników lub związek spółdzielni rolników na działalność określoną w art. 6 ust. 1 i 2 ustawy o spółdzielniach rolników, stanowiące własność albo będące $\mathrm{w}$ wieczystym użytkowaniu spółdzielni rolników lub związku spółdzielni rolników, które prowadzą działalność jako mikroprzedsiębiorstwo w rozumieniu załącznika I do rozporządzenia Komisji (UE) nr 651/2014. Zastosowanie tego zwolnienia jest także ograniczone. Odnosi się wyłącznie do budynków i budowli stanowiących własność, a jeżeli chodzi o grunty, może to być własność albo użytkowanie wieczyste. Zwolnienie jest adresowane tylko do mikroprzedsiębiorców.

$\mathrm{Z}$ uwagi na preferencje podatkowe powstaje pytanie o sprawdzenie, czy dana spółdzielnia jest spółdzielnią rolników. Grupy producentów rolnych, które także korzystają z preferencji podatkowych, podlegają wpisowi do odrębnego rejestru grup producentów rolnych. Nie ma zatem problemu z określeniem, czy dany podmiot uznany został za grupę producentów rolnych i może korzystać z preferencji podatkowych. Spółdzielnie rolników podlegają wpisowi tylko do Krajowego Rejestru Sądowego. Niektóre z dotychczas funkcjonujących spółdzielni miały już w nazwie

${ }^{41}$ Tekst jednolity: Dz. U. z 2019 r. poz. 1292 z późn. zm.

42 Tekst jednolity: Dz. U. z 2019 r. poz. 1170 z późn. zm. 
zwrot „spółdzielnia rolników”. Prawdopodobnie urzędy skarbowe będą żądały oświadczenia i potwierdzenia, że spółdzielnia rolników jest podmiotem spełniającym wymagania określone w ustawie o spółdzielniach rolników.

Według art. 25 ustawy o spółdzielniach rolników zwolnienia powyższe stanowią pomoc:

1) de minimis, o której mowa w rozporządzeniu Komisji (UE) nr 1408/2013 z dnia 18 grudnia 2013 r. w sprawie stosowania art. 107 i 108 Traktatu o funkcjonowaniu Unii Europejskiej do pomocy de minimis $\mathrm{w}$ sektorze rolnym ${ }^{43}-\mathrm{w}$ przypadku, gdy pomoc jest udzielana podmiotom prowadzącym działalność gospodarczą inną niż produkcja rolna. Uznanie pomocy za de minimis, czyli za niespełniającą wszystkich kryteriów określonych w art. 107 i 108 Traktatu łączy się z koniecznością spełnienia szeregu warunków określonych w rozporządzeniu nr 1408/2013, m.in. całkowita kwota pomocy de minimis przyznanej przez państwo członkowskie jednemu przedsiębiorstwu nie może przekroczyć 200000 euro w okresie 3 lat podatkowych;

2) de minimis $\mathrm{w}$ rolnictwie, o której mowa $\mathrm{w}$ rozporządzeniu Komisji (UE) nr 1408/2013 $3^{44}$ - w przypadku, gdy pomoc jest udzielana podmiotom prowadzącym produkcję rolną. Dnia 22 lutego 2019 r. Komisja Europejska opublikowała rozporządzenie Komisji (UE) 2019/316 z dnia 21 lutego 2019 r. zmieniające rozporządzenie (UE) nr 1408/2013 w sprawie stosowania art. 107 i 108 Traktatu o funkcjonowaniu Unii Europejskiej do pomocy de minimis w sektorze rolnym ${ }^{45}$. Z 15000 euro do 20000 euro w okresie 3 lat podatkowych zwiększona została pomoc de minimis dla jednego przedsiębiorstwa prowadzącego działalność w zakresie produkcji podstawowej produktów rolnych (gospodarstwa rolnego). Podwyższone limity obowiązują od 14 marca 2019 r. do 31 grudnia 2027 r. Mimo że pomoc $\mathrm{w}$ ramach zasady de minimis $\mathrm{w}$ rolnictwie jest popularna na wsi, żaden akt prawny nie zawiera katalogu środków zaliczanych do przedmiotowej pomocy oraz (co zostało już podkreślone) instytucji jej udzielających. Przede wszystkim należy wyróżnić pomoc

\footnotetext{
${ }^{43}$ Dz. Urz. UE L 352/1 z 24.12.2013, s. 1.

44 Tamże, s. 9.

45 Tamże, s. 1.
} 
polegającą na przyznaniu bezpośrednich korzyści (np. dopłaty do wapnowania, przy zakupie materiału siewnego, uprawie chmielu czy rzepaku) oraz zmniejszającą ciążące na podmiocie obowiązki publicznoprawne (np. umorzenie zobowiązań wobec KRUS, zwolnienia i ulgi w podatku rolnym). Inny podział to pomoc de minimis udzielana za pomocą instrumentów prawa cywilnego (umowa na wapnowanie, zawarcie umowy w sprawie umorzenia bądź rozłożenia na raty należności KOWR) albo prawa administracyjnego (np. zwolnienia czy ulgi podatkowe). Jego konsekwencją jest zróżnicowana procedura udzielania pomocy de minimis $\mathrm{w}$ rolnictwie, a potem ewentualna droga odwoławcza ${ }^{46}$;

3) de minimis, o której mowa w rozporządzeniu Komisji (UE) nr 717/2014 z dnia 27 czerwca 2014 r. w sprawie stosowania art. 107 i 108 Traktatu o funkcjonowaniu Unii Europejskiej do pomocy de minimis w sektorze rybołówstwa i akwakultury ${ }^{47}-\mathrm{w}$ przypadku, gdy pomoc jest udzielana podmiotom prowadzącym działalność $\mathrm{w}$ zakresie przetwórstwa i wprowadzania do obrotu ryb wytworzonych przez rolników.

\section{Spółdzielnia rolników jako spółdzielnia energetyczna}

Spółdzielnia rolników może także posiadać cechy charakterystyczne dla spółdzielni energetycznej. Zgodnie ze zmienioną definicją zawartą w ustawie z dnia 20 lutego 2015 r. o odnawialnych źródłach energii ${ }^{48} \mathrm{za}$ spółdzielnię energetyczną ${ }^{49}$ może zostać uznana spółdzielnia w rozumieniu ustawy Prawo spółdzielcze lub ustawy o spółdzielniach rolników, której przedmiotem działalności jest wytwarzanie energii elektrycznej lub biogazu, lub ciepła w instalacjach odnawialnego źródła energii

46 Zob. A. Suchon, Wybrane zagadnienia prawne pomocy de minimis w rolnictwie, Przegląd Prawa Rolnego 2011, nr 1, s. 173-198; taż, Nowe zasady pomocy de minimis w rolnictwie - aspekty prawne i ekonomiczne, Zeszyty Naukowe SGGW. Ekonomika i Organizacja Gospodarki Żywnościowej 2014, nr 107, s. 19-33.

47 Dz. Urz. UE L 190/45 z 28.06.2014, s. 45.

48 Tekst jednolity: Dz. U. z 2018 r. poz. 2389 z późn. zm.

49 Ustawa z dnia 19 lipca 2019 r. o zmianie ustawy o odnawialnych źródłach energii oraz niektórych innych ustaw, Dz. U. z 2019 r. poz. 1524. 
i równoważenie zapotrzebowania energii elektrycznej lub biogazu, lub ciepła wyłącznie na potrzeby własne spółdzielni energetycznej i jej członków, przyłączonych do zdefiniowanej obszarowo sieci dystrybucyjnej elektroenergetycznej o napięciu znamionowym niższym niż $110 \mathrm{kV}$ lub sieci dystrybucyjnej gazowej, lub sieci ciepłowniczej. Według art. 38f ustawy o odnawialnych źródłach energii przedmiotem działalności spółdzielni energetycznej może być wytwarzanie energii elektrycznej lub ciepła, lub biogazu w instalacjach odnawialnego źródła energii stanowiących własność spółdzielni energetycznej lub jej członków. Podmiot ten może korzystać z preferencji adresowanych dla tego rodzaju podmiotów po zamieszczeniu jej danych w wykazie spółdzielni energetycznych (prowadzi go Dyrektor Generalny Krajowego Ośrodka Wsparcia Rolnictwa). Spółdzielnia ta jest aktywna na obszarze gminy wiejskiej lub miejsko-wiejskiej w rozumieniu przepisów o statystyce publicznej lub na obszarze nie więcej niż trzech tego rodzaju gmin bezpośrednio sąsiadujących ze sobą.

\section{Zakończenie}

Dokonując podsumowania rozważań, przede wszystkim należy pozytywnie ocenić uchwalenie i wejście w życie ustawy o spółdzielniach rolników. Od kilku lat podejmowane były bowiem próby uchwalenia nowych przepisów dotyczących spółdzielni zarówno w odniesieniu do zasad ogólnych, jak i wybranych branż, np. spółdzielni rolników. Działania te mają już pewną historię, o czym świadczą projekty aktów prawnych ${ }^{50}$.

${ }^{50}$ Np. projekt ustawy Prawo spółdzielcze przygotowany przez zespół ekspertów powołany przez Prezydenta RP Aleksandra Kwaśniewskiego (wrzesień 2004 r.); Projekt ustawy przygotowany przez Komisję Nadzwyczajną Sejmową IV kadencji (2005 r.). Przykładowo w 2012 r. złożono do Sejmu RP kilka projektów ustaw z zakresu prawa spółdzielczego, a w styczniu 2013 r. powołana została komisja nadzwyczajna do ich rozpatrzenia. Jej prace dotyczyły tylko części ogólnej ustawy, ale nie została ona uchwalona. W przypadku spółdzielni rolniczych warto wspomnieć o projekcie Polskiego Stronnictwa Ludowego z 2004 r. Był to projekt ustawy o spółdzielniach rolniczych, niemniej przepisy odnosiły się tylko do spółdzielni rolników. Wprowadzenie takich spółdzielni do naszego systemu prawnego zostało zaproponowane także w 2012 r. przez Prawo i Sprawiedliwość w przedłożonym do Sejmu projekcie (poselski projekt ustawy o spółdzielniach rolników, https:// krdp.pl/files/aktyprawne/241.pdf [dostęp: 1.08.2017 r.]), ustawa nie została jednak uchwalona. 
Nie ulega wątpliwości, że wprowadzenie odrębnego pojęcia spółdzielni rolników do krajowego systemu prawnego, instrumentów prawnych ułatwiających zakładanie i funkcjonowanie tego rodzaju spółdzielni stanowią istotny czynnik rozwoju teorii prawa spółdzielczego i wpisują się w europejskie tendencje rozwoju spółdzielczości ${ }^{51}$.

Nawiązując do celu artykułu, czyli próby ustalenia, które z regulacji prawnych mogą zachęcać producentów rolnych do organizowania takich podmiotów albo stanowić w tym względzie bariery, stwierdzić należy, że do tych pierwszych zaliczyć można szeroko określony przedmiot działalności. Spółdzielnie rolników są adresowane głównie do producentów rolnych, jednocześnie dla prawidłowego funkcjonowania wskazane jest zaangażowanie innych podmiotów. Dlatego trzeba ocenić pozytywnie członkostwo osób fizycznych i prawnych, które nie prowadzą działalności rolniczej, ale są aktywne w zakresie przechowywania, magazynowania, sortowania, pakowania lub przetwarzania produktów rolnych lub grup tych produktów, lub ryb wytworzonych przez rolników albo prowadzą działalność usługową wspomagającą rolnictwo, obejmującą świadczenie na rzecz rolników. Spółdzielcy tacy nie mogą być wybierani do rady nadzorczej. Na uwagę zasługują regulacje w zakresie przekazania udziałów (chociaż niektóre sformułowania przepisów mogą budzić wątpliwości interpretacyjne), tworzenia związków spółdzielni rolników oraz preferencje podatkowe $\mathrm{w}$ podatku od nieruchomości oraz podatku dochodowym od osób fizycznych.

Przeprowadzone analizy wykazały, że do cech charakterystycznych spółdzielni rolników wynikających z nowej ustawy o spółdzielniach rolników zaliczyć należy przede wszystkim przedmiot działalności oraz członkostwo rolników i nierolników spełniających określone wymagania. Inne specyficzne rozwiązania zawarte $\mathrm{w}$ omawianym akcie prawnym na tle ustawy Prawo spółdzielcze dotyczą np. przekazania udziałów (chociaż niektóre sformułowania przepisów mogą budzić wątpliwości interpretacyjne), dodatkowych postanowień, które mają być ujęte w statucie spółdzielni, tworzenia związków spółdzielni rolników oraz preferencji

${ }^{51} \mathrm{~W}$ niektórych państwach europejskich to właśnie dzięki rozszerzaniu przedmiotu działalności spółdzielni i dostosowaniu go do potrzeb rolnictwa oraz wymogów Wspólnej Polityki Rolnej podmioty spółdzielcze są w dobrej kondycji finansowej i w dużym stopniu wspierają gospodarstwa rolne spółdzielców. Zob. szerzej A. Suchoń, Prawna koncepcja..., s. 66 i n. oraz wskazana tam literatura. 
podatkowych w podatku od nieruchomości oraz podatku dochodowym od osób fizycznych. Jednocześnie trzeba podkreślić, że również na podstawie ogólnego Prawa spółdzielczego mogły być zakładane spółdzielnie, które prowadzą podobną czy taką samą działalność jak spółdzielnie rolników, a jej członkami są rolnicy i nierolnicy. Utworzenie jednak i spełnienie przez spółdzielnię wymagań z ustawy o spółdzielniach rolników pozwala na skorzystanie ze specjalnych rozwiązań zawartych w tej regulacji oraz preferencji podatkowych określonych $\mathrm{w}$ wielu ustawach.

W opinii autorki niezbędne byłoby rozważanie wprowadzenia kilku zmian do omawianego aktu prawnego. W obecnym kształcie ustawa o spółdzielniach rolników może nie przyczynić się do ożywionego tworzenia tych organizacji. W aktualnych warunkach prawnych i społecznych powstanie takich podmiotów może być trudne. Niektóre z regulacji prawnych mogą bowiem stanowić barierę w rozwoju spółdzielni. Jedną z nich jest wymóg 10 członków rolników. W niektórych gminach nie występuje obecnie tak duża liczba producentów rolnych tego samego produktu. Oczywiście, ustawa nie wprowadza zasady regionalizacji, ale funkcjonowanie spółdzielni, których członkami są producenci z różnych, często odległych miejscowości może wiązać się z trudnościami.

Jeżeli chodzi o minimalną liczbę członków, zasadne wydaje się wprowadzenie 5 producentów rolnych. Liczba taka odnosi się obecnie do spółdzielczych grup producentów rolnych. Mniejsza liczebność spółdzielców występuje także $\mathrm{w}$ innych systemach prawnych, $\mathrm{np}$. w Niemczech - 3, a we Francji - 7. W przypadku wprowadzenia mniejszej liczby producentów rolnych konieczne byłoby postanowienie, że liczba członków spółdzielni rolników niebędących rolnikami nie może przekroczyć $50 \%$.

Odwołanie się przy określaniu rolników jako podstawowych członków spółdzielni rolników do definicji gospodarstwa rolnego z ustawy o podatku rolnym (która budzi wątpliwości interpretacyjne) wydaje się dyskusyjne. Być może lepszym rozwiązaniem byłoby wprowadzenie na potrzeby ustawy o spółdzielniach rolników odrębnej definicji. Jak zostało już zaakcentowane, pozytywne ocenić należy szeroko określony przedmiot działalności spółdzielni, obejmujący nie tylko koncentrację podaży oraz organizowania zbycia produktów lub grup produktów wyprodukowanych przez rolników, ale także m.in. przetwarzanie produktów lub grup produktów, wyprodukowanych przez rolników, oraz obrót uzyskanymi w ten sposób produktami przetworzonymi. Z ustawy o spółdzielniach rolników nie wynika bezpośrednio angażowanie się tego podmiotu 
w rozwój energii odnawialnej z wykorzystaniem surowców rolniczych, produktów ubocznych rolnictwa, płynnych lub stałych odchodów zwierzęcych lub pozostałości z przetwórstwa produktów pochodzenia rolniczego albo biomasy leśnej czy też gruntów członków, gdzie mogłyby zostać zainstalowane elektrownie wiatrowe czy fotowoltaika. Jednakże nowelizacja z dnia 19 lipca 2019 r. o zmianie ustawy o odnawialnych źródłach energii określa, że spółdzielnia rolników może zostać uznana za spółdzielnię energetyczną, jeżeli spełnia przesłanki przewidziane dla tego rodzaju spółdzielni. W trosce o jasność interpretacji zasadne jest rozważanie poszerzenia przedmiotu działalności fakultatywnej spółdzielni rolników o aktywność w zakresie energii odnawialnej w ustawie o spółdzielniach rolników.

Dla trwałości spółdzielni bardziej odpowiednie byłoby wprowadzenie dłuższego zarówno okresu minimalnego członkostwa w spółdzielni, np. 5 lat, jak i terminu wypowiedzenia. Jednocześnie może to stanowić dla niektórych podmiotów czynnik zniechęcający do zakładania czy nabywania członkostwa w spółdzielni. Z kolei dla dalszego rozwoju zrzeszania się producentów rolnych korzystna byłaby interpretacja, w myśl której już funkcjonujące spółdzielcze grupy producentów rolnych, jeżeli będą spełniały wskazane $\mathrm{w}$ ustawie $\mathrm{z}$ o spółdzielniach rolników wymagania, po uzupełnieniu statutu i nazwy o zwrot „spółdzielnie rolników” (w Krajowym Rejestrze Sądowym) będą uznane za takie podmioty.

Uzasadnione wydaje się rozważanie wprowadzenia wsparcia finansowego dla spółdzielni rolników na rozwój działalności, podobnie jak korzystają z niego grupy producentów rolnych. Instrument taki może stanowić istotny czynnik zachęcający do tworzenia spółdzielni rolników. Środki mogłyby pochodzić z budżetu krajowego albo unijnego w ramach planu strategicznego ${ }^{52}$. W 2019 i 2020 r. grupy producentów rolnych mogą starać się jeszcze o środki unijne na podstawie rozporządzenia Ministra Rolnictwa i Rozwoju Wsi z dnia 2 sierpnia 2016 r. w sprawie szczegółowych warunków i trybu przyznawania, wypłaty oraz zwrotu pomocy finansowej

52 Zob. projekt rozporządzenia Parlamentu Europejskiego i Rady ustanawiający przepisy dotyczące wsparcia na podstawie planów strategicznych sporządzanych przez państwa członkowskie $\mathrm{w}$ ramach wspólnej polityki rolnej (planów strategicznych WPR) i finansowanych z Europejskiego Funduszu Rolniczego Gwarancji (EFRG) i z Europejskiego Funduszu Rolnego na rzecz Rozwoju Obszarów Wiejskich (EFRROW), COM/2018/392 final - 2018/0216 (COD), https://eur-lex.europa.eu/legal-content/PL/ ALL/?uri=CELEX:52018PC0392 [dostęp: 1.08.2019 r.]. 
w ramach działania „Tworzenie grup producentów i organizacji producentów". Zasadna wydaje się interpretacja, że spółdzielnia rolników, o ile będzie spełniała wymagania z ustawy o grupach producentów rolnych, może złożyć wniosek o wpis do rejestru grup producentów rolnych czy też organizacji producentów rolnych i starać się o wyżej wymienione wsparcie finansowe. W opinii autorki spółdzielnie rolników spełniające wymagania wynikające z przepisów prawnych (np. ustawy z dnia 20 kwiet-

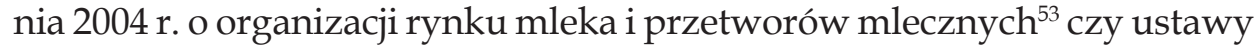
z dnia 11 marca 2004 r. o organizacji niektórych rynków rolnych ${ }^{54}$ ) mogą zostać uznane za organizacje producentów rolnych. Podmioty takie z kolei mogą starać się o środki finansowe oraz korzystać z innych instrumentów polskich i unijnych adresowanych do tych organizacji.

\section{Bibliografia}

Bieluk J., Działy specjalne produkcji rolnej. Problemy prawne, Białystok 2013.

Bieluk J., Pojęcie działalności rolniczej w ustawach o podatku dochodowym od osób fizycznych i od osób prawnych, Przegląd Prawa Rolnego 2008, nr 2 (4).

Bieluk J., Spótdzielnie rolników - konstrukcja prawna, Studia Iuridica Agraria 2018, t. 16.

Bierzanek R., Prawo spótdzielcze w zarysie, Warszawa 1984.

COGECA, Agricultural Cooperatives in Europe. Main Issues and Trends, Brussels 2010. COGECA, Development of Agricultural Cooperatives in the EU, Brussels 2014.

Chrzanowski W., Nowe prawo spótdzielcze, analiza zmian, Warszawa 1983.

Gajda J., Królikowska K., Pietrzykowski K., Pisuliński J., Zakrzewski P., Spótdzielniemieszkaniowe, w: System Prawa Prywatnego, t. 21. Prawo spótdzielcze, red. K.Pietrzykowski, Warszawa 2020.

53 Tekst jednolity: Dz. U. z 2019 r. poz. 1430 z późn. zm.

54 Tekst jednolity: Dz. U. z 2018 r. poz. 945, z 2019 r. poz. 2020. Rozporządzenie z dnia 7 stycznia 2016 r. w sprawie uznawania organizacji producentów i zrzeszeń organizacji producentów oraz organizacji międzybranżowych funkcjonujących na rynkach rolnych innych niż rynki mleka i przetworów mlecznych oraz owoców i warzyw (Dz. U. z 2016 r. poz. 87) zmienione przez rozporządzenie Ministra Rolnictwa i Rozwoju Wsi z dnia 27 czerwca 2019 r. zmieniające rozporządzenie w sprawie uznawania organizacji producentów i zrzeszeń organizacji producentów oraz organizacji międzybranżowych funkcjonujących na rynkach rolnych innych niż rynki mleka i przetworów mlecznych oraz owoców i warzyw (Dz. U. z 2019 r. poz. 1293). 
Gersdorf M., w: M. Gersdorf, J. Ignatowicz, Prawo spótdzielcze. Komentarz, Warszawa 1985.

Jedlińska M., Spółdzielnie socjalne, w: System Prawa Prywatnego, t. 21. Prawo spótdzielcze, red. K. Pietrzykowski, Warszawa 2020.

Jurcewicz A., Traktatowe podstawy unijnego prawa rolnego w świetle orzecznictwa. Zagadnienia wybrane, Warszawa 2012.

Jurcewicz A., Popardowski P., Zięba J., Prawne podstawy wspólnej polityki rolnej, w: Prawo i polityka rolna Unii Europejskiej, red. A. Jurcewicz, Warszawa 2010.

Klein A., Ewolucja instytucji osobowości prawnej, w: Tendencje rozwoju prawa cywilnego, red. E. Łętowska, Warszawa 1993.

Miączyński A., Ochrona praw członka spółdzielni, Zeszyty Naukowe Uniwersytetu Jagiellońskiego. Prace Prawnicze 1981, nr 98.

Miemiec M., Pojęcie statutu w nauce prawa, Acta Universitatis Wratislaviensis. Prawo 1975, nr 318.

Organizacja mazowieckiego rynku rolnego poprzez tworzenie grup producentów rolnych na bazie prawa spótdzielczego, red. W. Boguta, Z. Gumowski, K. Lachowski, Warszawa 2007.

Pietrzykowski K., Powstanie i ustanie stosunku członkostwa w spótdzielni, Warszawa 1990.

Pietrzykowski K., Spółdzielnie mieszkaniowe. Komentarz, 2013 [baza danych Legalis].

Pietrzykowski K., Pojęcie spótdzielni, w: System Prawa Prywatnego, t. 4. Prawo rzeczowe, red. Gniewek E., Warszawa 2007.

Popiołek H., Stanowisko prawne członków rady i zarządu spółdzielni, Warszawa 1970.

Radwański Z., Teoria umów, Warszawa 1977.

Suchoń A., Jeszcze o pojęciu działalności rolniczej, Rejent 2017, nr 12.

Suchoń A., Komentarz do przepisów o dzierżawie (art. 693-709 KC), w: Kodeks cywilny, t. 2. Komentarz. Art. 353-626, red. M. Gutowski, Warszawa 2018.

Suchon A., Legal aspects of the organisation and operation of agricultural co-operatives in Poland, Poznań 2019.

Suchon A., Nowe zasady pomocy de minimis w rolnictwie - aspekty prawne i ekonomiczne, Zeszyty Naukowe SGGW. Ekonomika i Organizacja Gospodarki Żywnościowej 2014, nr 107.

Suchoń A., Prawna koncepcja spótdzielni rolniczych, Poznań 2016.

Suchoń A., Spótdzielczość w rolnictwie i na obszarach wiejskich, w: Prawo rolne, red. P. Czechowski, Warszawa 2019.

Suchón A., Spółdzielnie w rolnictwie i na terenach wiejskich we Włoszech, Kwartalnik Prawa Prywatnego 2013, t. 22, nr 4.

Suchoń A., Uwagi na tle projektu ustawy o spótdzielniach rolników, Przegląd Prawa Rolnego 2017, nr 2.

Suchoń A., Wpływ polityki i prawa Unii Europejskiej na rozwój spótdzielni rolniczych w wybranych krajach członkowskich, Przegląd Prawa Rolnego 2015, nr 1. 
Suchoń A., Wybrane zagadnienia prawne w pomocy de minimis $w$ rolnictwie, Przegląd Prawa Rolnego 2011, nr 1.

Suchoń A., Z prawnej problematyki zakładania i prowadzenia działalności przez spótdzielcze grupy producentów rolnych, Przegląd Prawa Rolnego 2012, nr 2.

Suchoń A., Z problematyki podatku rolnego, Przegląd Prawa Rolnego 2007, nr 2.

Suchoń A., Zrzeszanie się producentów rolnych, w: E. Klat-Górska, M. Korzycka, E. Kremer, P. Księżak, A. Suchoń, P. Wojciechowski, Instytucje prawa rolnego, Warszawa 2019.

Wierzbowski M., Akty normatywne organizacji spótdzielczych, Warszawa 1977.

Wróblewski S., Ustawa o spótdzielniach, Kraków 1921.

Zakrzewski P., Majątek spótdzielni, Warszawa 2003.

Zakrzewski P., Zasady Międzynarodowego Zwiazku Spótdzielczego, Kwartalnik Prawa Prywatnego 2005, t. 14, nr 1.

\section{Streszczenie}

Celem artykułu jest określenie prawnych uwarunkowań tworzenia i prowadzenia działalności przez spółdzielnie rolników oraz próba ustalenia, które z regulacji prawnych mogą zachęcać producentów rolnych do organizowania takich podmiotów albo stanowić bariery $\mathrm{w}$ tym zakresie. Rozważania rozpoczyna wskazanie cech charakterystycznych spółdzielni rolników na tle innych podmiotów spółdzielczych, a wynikających z nowej ustawy z dnia 4 października 2018 r. o spółdzielniach rolników. Następnie zaprezentowana została procedura zakładania spółdzielni rolników. Szczególna uwaga została zwrócona na statut, organy spółdzielni, zagadnienie udziałów i wkładów. W dalszej kolejności autorka stara się ustalić, czy działające spółdzielnie, w tym spółdzielcze grupy producentów rolnych, spółdzielcze organizacje producentów rolnych (także owoców i warzyw), spełniające wymagania wskazane w ustawie z dnia 4 października 2018 r. będą mogły zostać uznane za spółdzielnie rolników. W ramach studium poruszone zostało także zagadnienie instrumentów finansowych mających zachęcić do zakładania spółdzielni rolników (preferencje w podatku od nieruchomości oraz podatku dochodowym od osób prawnych) w aspekcie pomocy de minimis oraz pomocy de minimis $\mathrm{w}$ rolnictwie.

W podsumowaniu autorka stwierdziła m.in., że należy ocenić pozytywnie uchwalenie i wejście w życie ustawy z dnia 4 października 2018 r. o spółdzielniach rolników. Od kilku lat podejmowane były bowiem próby uchwalenia nowych przepisów dotyczących spółdzielni zarówno w odniesieniu do zasad ogólnych, jak i wybranych branż, w tym spółdzielni rolników. Jednocześnie w obecnym kształcie ustawa o spółdzielniach rolników może nie przyczynić się do ożywionego zainteresowania ruchem spółdzielczym na obszarach wiejskich i tworzenia 
tych organizacji. Dlatego autorka proponuje rozważanie wprowadzenia kilku zmian do nowego aktu prawnego.

Słowa kluczowe: spółdzielnie rolników, spółdzielczość, działalność rolnicza, spółdzielcze grupy producentów rolnych, spółdzielnie energetyczne

\section{NEW ACT ON FARMERS' COOPERATIVES - SELECTED ISSUES}

\section{Sum mary}

The purpose of this article is to determine the legal conditions for setting up and running an activity by farmers' cooperatives and an attempt at establishing which of the legal regulations may encourage agricultural producers to organize such entities, and which impose barriers. The author starts by indicating the characteristic features of farmers' cooperatives against other cooperative entities, which result from the new Act of 4 October 2018. Next, the procedure required to set up a farmers' cooperative is presented. Special attention has been given to the cooperative's statute, its bodies, and to the issues of shares and contributions. Subsequently, the author tried to establish whether the functioning cooperatives, including cooperative groups of agricultural producers and organizations of agricultural producers (also of fruit and vegetables), which meet the criteria laid down in the Act of 4 October 2018, will be able to qualify as farmers' cooperatives. The author's considerations also address the issue of financial incentives, which are meant to encourage farmers to set up cooperatives (preferential real estate tax and corporate income tax rates), within the aspect of de minimis aid and de minimis aid in agriculture.

In the summary, the author states, among others, that the passing and entering into effect of the Act of 4 October 2018 on farmers' cooperatives must be evaluated positively. Attempts to pass new provisions regarding cooperatives, both in general and in relation to chosen industries, such as farmers, have been made a number of times in the past years. At the same time, in its current shape, the Act of 4 October 2018 cannot contribute to a large-scale interest in the cooperative movement in rural areas, nor to the setting up of farmers' cooperatives. For the above reasons, the author proposes that some changes be introduced to the new legal act.

Key words: farmers' cooperatives, cooperativeness, agricultural activity, cooperative groups of agricultural producers, energy cooperatives 


\section{НОВЫЙ ЗАКОН О СЕЛЬСКОХОЗЯЙСТВЕННЫХ КООПЕРАТИВАХ - ИЗБРАННЫЕ ВОПРОСЫ}

\section{Резюме}

Цель статьи - определить правовые условия для создания и ведения бизнеса сельскохозяйственными (фермерскими) кооперативами и попытаться определить, какие правовые нормы могут побуждать сельскохозяйственных производителей к созданию таких организаций или создавать препятствия в этом отношении. Исследование начинается с определения характеристик сельскохозяйственных кооперативов по сравнению с другими кооперативными образованиями в свете нового Закона от 4 октября 2018 года о сельскохозяйственных кооперативах. Затем была представлена процедура создания сельскохозяйственного кооператива. Особое внимание было уделено уставу, кооперативным органам, а также вопросу паев и вкладов. Далее автор пытается определить, будут ли действующие кооперативы, в том числе кооперативные группы сельскохозяйственных производителей, кооперативные организации сельскохозяйственных производителей (включая производителей фруктов и овощей), отвечающие требованиям, изложенным в Законе от 4 октября 2018 года, иметь право на признание их сельскохозяйственными кооперативами. В исследовании также рассматривается вопрос финансовых инструментов для поощрения создания сельскохозяйственных кооперативов (льготы по налогу на недвижимость и корпоративному подоходному налогу) с точки зрения помощи de minimis и помощи de minimis в сельском хозяйстве.

В резюме автор, среди прочего, заявляет, что принятие и вступление в силу Закона от 4 октября 2018 г. о сельскохозяйственных кооперативах следует оценить положительно. В течение нескольких лет предпринимались попытки ввести в действие новые положения о кооперативах как в отношении общих принципов, так и отдельных отраслей, включая сельскохозяйственные кооперативы. В то же время в его нынешней форме Закон о сельскохозяйственных кооперативах может не способствовать повышению интереса к кооперативному движению в сельских районах и созданию этих организаций. Поэтому автор предлагает рассмотреть возможность внесения некоторых изменений в новый правовой акт.

Ключевые слова: сельскохозяйственные кооперативы, кооперация, сельскохозяйственная деятельность, кооперативные группы сельскохозяйственных производителей, энергетические кооперативы 